\title{
Lorenz Frølich og arkæologien
}

af lektor, mag.art. Klaus Ebbesen

Lorenz Frølich er en af vores største illustratorer. En gudbenådet kunstner, hvis tegninger har ætset sig ind på nethinden af det danske folks selvforståelse. Illustrationerne til H.C. Andersens eventyr og A. Fabricius' Danmarkshistorie er klassiske indenfor dansk bogillustration.

Det kræver stort talent som tegner, at kunne fremkalde en situation så levende, at den står uudsletteligt i et folks erindring. Lorenz Frølich, eller Lars Glad som ungdomsvennerne kaldte ham, evnede det tilsyneladende legende let.

Selv har han forklaret, at når han havde hørt en fortælling eller en historie, som gjorde indtryk på ham, stod hvert optrin så levende for ham, at han straks kunne tegne det. Det gjorde han så. Talentet var ikke alene stort, men også frodigt. Under et ophold i Rom, 1846-48, løb pennen så hurtigt over papiret, at tjenestepigen uden videre kunne bruge af bunken med tegninger, når hun skulle tænde op i kaminen!

\section{Lorenz Frølich}

Lorenz Frølich blev født i 1820. Han voksede op i et københavnsk rigmandshjem. Han interesserede sig for tegning allerede fra de tidligste drengeår; en interesse som forældrene i høj grad stimulerede. Som 20-årig kom Frølich på en større dannelsesrejse til Sydtyskland, hvor han blev i flere år. Derfra gik turen videre til Italien. Flere år senere vendte han tilbage til Kobenhavn, men blot for at flytte til Paris allerede i 1851. L. Frølich boede i Paris til 1875. Det år vendte han endeligt hjem til København, hvor oldingen døde i 1908; hædret som en af nationens store mænd. ${ }^{1}$

Størstedelen af sit voksenliv levede og arbejdede Lorenz Frølich således i 
udlandet. I Frankrig er han først og fremmest kendt for sine tegnede børnebøger. Ialt ca.1500 tegninger blev det til.

L. Frølich var vant til at arbejde i Europas store kulturbyer. Måske netop derfor kunne han fange og videregive det typisk danske i sine tegninger fra den nordiske oldtid. L. Frølichs tegninger ejer tillige det mundtlige sagns forkærlighed for den enkle skikkelse. De ejer samme evne til at lade en persons væsen udfolde sig i handling. Derfor kommer Frølichs talent måske til den bedste udfoldelse i illustrationerne af de gamle fortællinger om nordiske guder og helte. "Det er fortidens epos, der får sin virkeliggørelse ved Frølichs blyant", som historikeren Axel Olrik skrev engang.

Axel Olrik tilføjer at "Kulturhistorisk Nøjagtighed vilde sikkert have været den rene Fordærvelse for en Billedverden som denne".2 Deri tager Axel Olrik dog fejl. Selve kompostionen er lånt fra det middelalderlige Bayeux-tapet. En billedanalyse viser endvidere, at Lorenz Følich har gengivet en række nordiske oldsager gansk korrekt, omend de fleste optræder på de mærkeligste tidspunkter.

\section{Det var Skræp, som sang}

Stendysserne og jættestuerne var et yndet motiv for de romantiske malere. Derfor var det kun naturligt, at den 19-årige Lorenz Frølich tegnede storstensgrave under et ophold på Møn i 1839. Der er bevaret en farvelagt tegning af jættestuen ved Sparreminde. Man ser det indre af jættestuens kammer med en bondedreng som målestok. Tegningen er uden større inspiration. Anderledes kraft er der i en vikingetidig kampscene, som Frølich tegnede samme år. En bande vikinger angriber en gård. Den kampklare bonde har allerede fældet et par stykker, og holder sværdet hævet til et nyt hug. Husets kønne, langhårede frue gemmer sig bag sin mands brede ryg. Drengen på gården har grebet et langsværd for at hjælpe sin far, mens hans søster knælende strækker armene mod himlen i en bøn om hjælp. Bondens sværd er særlig interessant. Det er meget detaljeret tegnet og fæstet levner ingen tvivl om, at det tilhører Egtvedpigens tid. Helt nøjagtigt er der tale om et fuldgrebssværd fra bronzealderens Per. II, eller ca. 15-1200 f.v.t. Det er et stiksværd, og ikke et hugsværd, men det vidste hverken arkæologer eller andre i 1830-erne.

Lorenz Frølich kan kun have set et sådant sværd ét sted, nemlig på Oldnordisk Museum. Det fremgår da også af et par breve, som Joh. TH. Lundbye i begyndelsen af 1840-erne sender til L. Frølich i München, at bestyreren for Oldnordisk Museum, C.J. Thomsen, var en fælles bekendt. C.J. Thomsen, der få år 


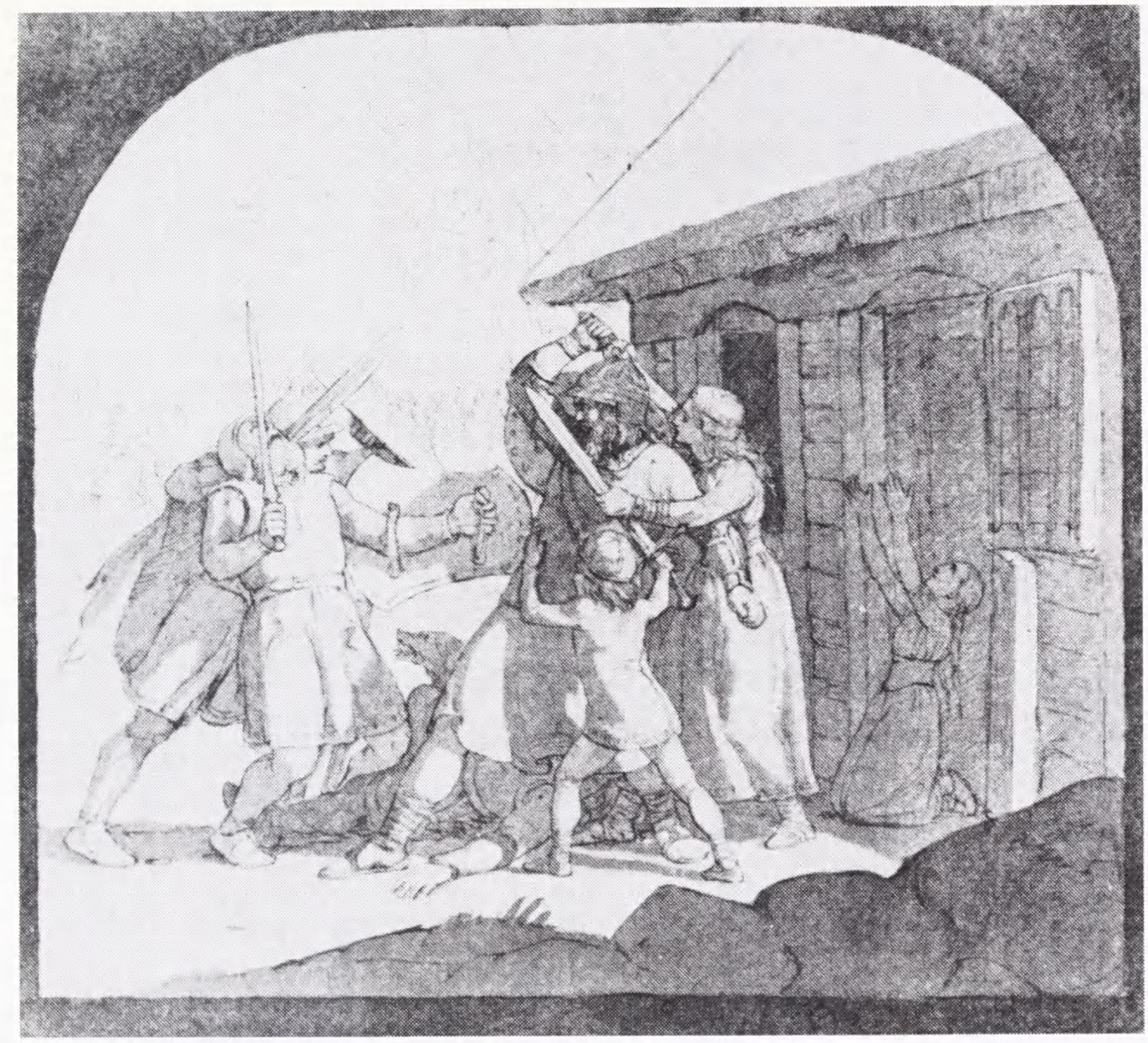

L. Frølich: Kampscene, 1839. Sværdet til højre er gengivet efter C.J. Thomsen Ledetraad til Nordisk Oldkyndighed, 1836, hvis tegning af bronzesværdet ses yderst til højre.

forinden havde inddelt oldtiden i en sten-, bronze,- og jernalder, sender hilsner til Frølich gennem Lundbye. Frølichs kompositioner skal have glædet skaberen af 3-periode-systemet, skriver Lundbye, idet han tilføjer "og det er virkelig sandt". I C.J. Thomsens lille skrift Ledetråd til Nordisk Oldkyndighed, fra 1836 finder man en tegning af det samme bronzesværd. Den er lavet så omhyggeligt, at sværdet kan identificeres i Nationalmuseets samlinger. ${ }^{3}$

Sværdet er fundet i 1830 af gårdejer Peder Nielsen i Føllenslev udenfor Kalundborg. Peder Nielsen fandt sværdet, da han første gang pløjede på en eng, som tidligere havde været mose. Det fremkom kun et par bøsseskud fra det sted, hvor der tidligere har stået et stort slag. I hvert fald ifølge et lokalt sagn. Sværdet blev indløst af hans majestæt kongen, som allerunderdanigst tilstillede bonden $20 \mathrm{Rd}$. rent sølv for sværdet.

Det samme broncealdersværd, eller et lignende, dukker senere op i hånden på Uffe hin Spage. 


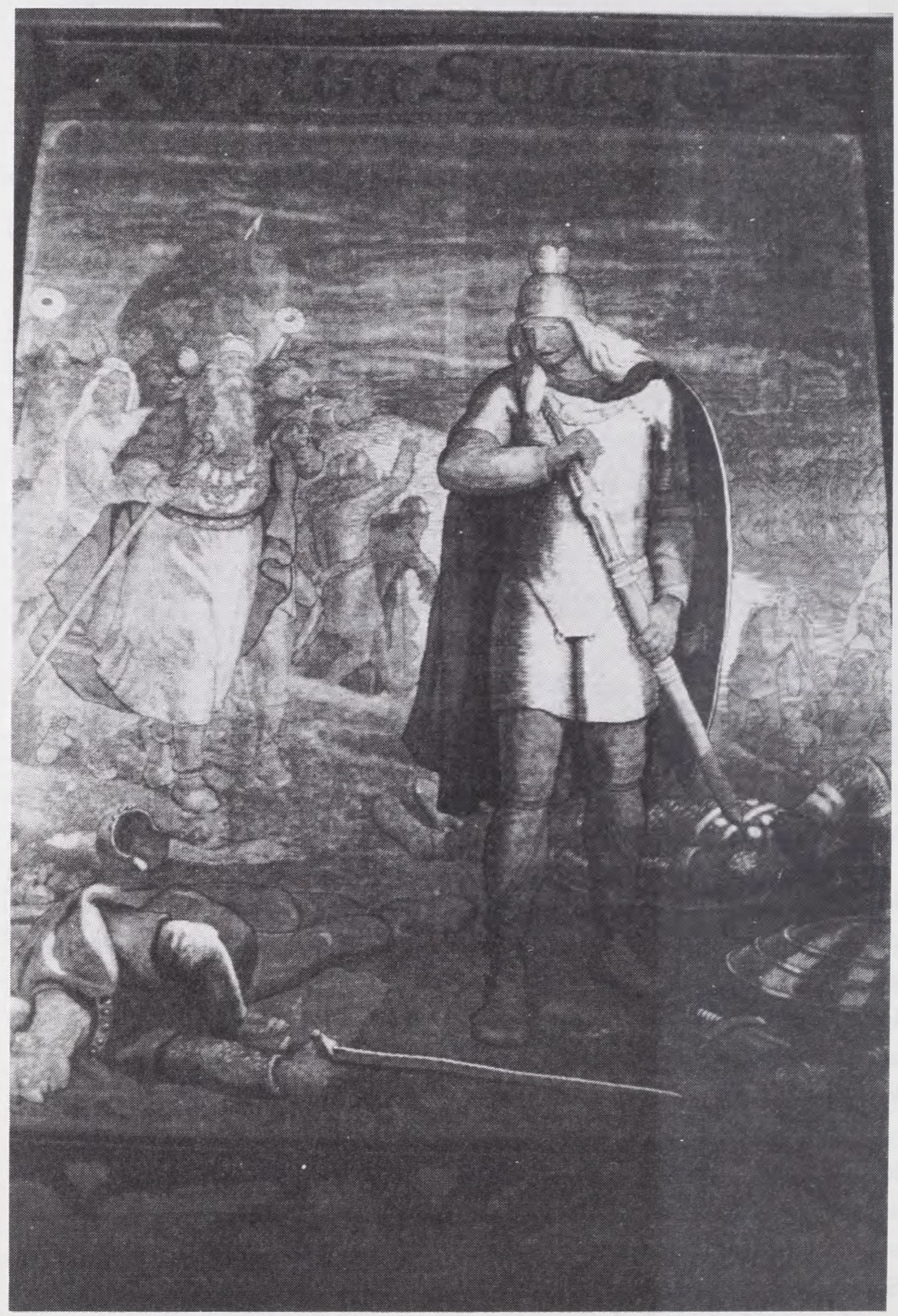

L. Frølich: Uffe hin Spage. Gobelin på Københavns Rådhus. Gertrud Permin foto. 
Lorenz Frølich arbejdede næsten hele livet med Uffe-motivet. Der foreliger en hel serie af forskellige tegninger og malerier. Den bedst kendte er illustrationen til A. Fabricius' Danmarkshistorie fra 1852. Den her mest interessante hænger på Københavns Rådhus.

I forbindelse med Lorenz Frølichs 80 års fødselsdag besluttedes det at lave en serie historiske gobeliner til ophængning på Københavns Rådhus. Frølich deltog selv i arbejdet. Til brug for Uffe-billedet fandt han sine gamle skitser og tegninger frem. ${ }^{4}$

Resultatet blev, at Uffe hin Spage kom til at forsvare fædrelandet med et sværd fra ældre bronzealder. Hos Saxo læser man, at sværdet Skræp måtte graves op af jorden til tvekampen.Det var stærkt medtaget af rust efter den lange tid i jorden. Det troede man gerne. For på Saxos tid havde det pågældende sværd tilbragt 2 1/2 årtusind i jorden. Men sværdet bed godt nok alligevel. Som bekendt endte tvekampen med dansk sejr og fædrelandets frelse.

På det samme billede af tvekampen i Ejderen er den danske hær iøvrigt udstyret med vejende faner og lurer fra bronzealderen.

Også bronzelurerne er godt 2000 år ældre end den engelske kong Offa, han som har leveret materiale til sagnet om Vermund og Uffe.

En anden af gobelinerne på Københavns Rådhus forestiller "Kampen på Samsø" mellem Hjalmar og bersærken Angantyr. Begge bliver dræbt i tvekampen, Hjalmar af det berømte sværd Tyrfing. Sværdet i hans egen hånd minder $\mathrm{i}$ betænkelig grad om en forstørret udgave af en flintdolk med fiskehalefæste (type IV) fra sen bondestenalder, eller ca. år 2000 f.v.t. ${ }^{5}$

\section{Den ældre Eddas Gudesange}

Thors hammer hed Mjølner. Den havde mange gode egenskaber. Når Thor kastede den, ramte den altid. Den trængte igennem alt og vendte af sig selv tilbage til Thors hånd. Hammeren havde dog én skavank. Skaftet var for kort. Det skyldtes efter sigende, at den dværg, som smedede hammeren, blev stukket af en hveps, mens han lavede den.

Skavanken med det korte skaft er en stor fordel for os arkæologer. Mjølner er let genkendelig, når den optræder i de arkæologiske fund.

I vikingetiden blev "Thorshamre en miniature" hyppigt brugt som smykker af både mænd og kvinder. Der kendes ca 500 stykker fra hele Nordeuropa. De dokumenterer, at man i hele vikingetiden (ca. 725-1050 e.v.t.) troede på Thor, fra Grønland i vest til Rusland i øst.

Det ville være nærliggende, om Frølich havde udstyret sine Thor-figurer med 
en tegning af disse miniature-økser. Mærkelig nok er det ikke tilfældet. I stedet optræder Thor sædvanligvis med mærkelige fantasi-hamre.

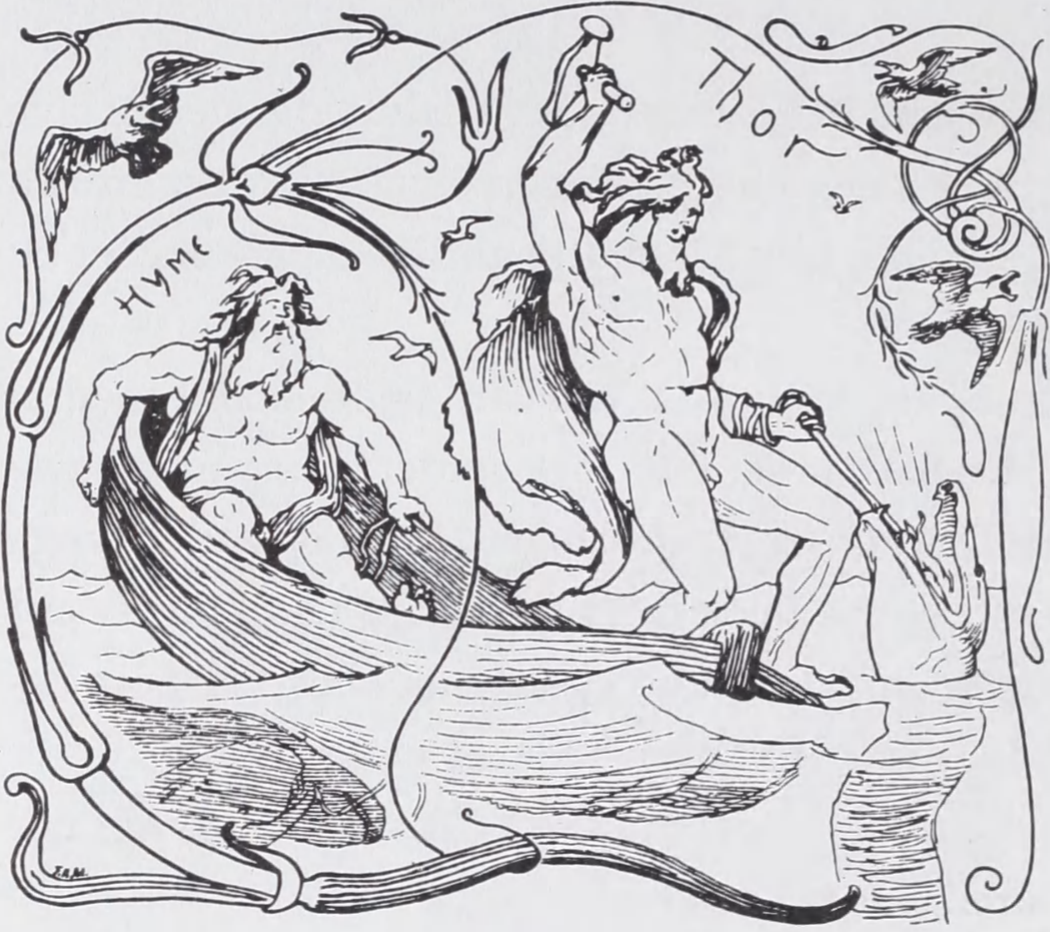

L. Frølich: Thors fiskedræt. Den ældre Eddas Gudesange, 1895.

III) tilhører tiden omkring år 3.500 f.v.t. og var en slags værdighedstegn for de første danske stenalderhøvdinge.

De flot svungne bronzelurer er nogle af de mest karakteristiske, danske oldsager. De stammer fra midten af bronzalderen, omkring år 1000 f.v.t. De blev brugt to og to sammen ved tidens hellige fester. Teknisk er det meget avancerede musikinstrumenter; nogle af de ældste blæseinstrumenter i verden. Det er derfor oplagt, at guden Heimdal i Frølichs tegninger skal udstyres med en lur. I mytologien holder Heimdal vagt ved foden af regnbuen Rimfrost, som fører til gudernes bolig. Han har et horn, Gjallerhorner. Med Gjallerhornet blæser Heimdal guderne til samling ved verdens undergang, Ragnarok.

I Den ældre Eddas gudesange blæser Heimdal til Ragnarok-kampen på en bronzelur, som ca. år 1750 blev fundet ved Tellerup på Fyn. Han holder den med mundingen nedad, ganske som arkæologerne givelse i 1895 af Den ældre Eddas gudesange har Frølich dog foretaget studier af de nordiske oldsager. ${ }^{6}$ Under den berømte fisketur, hvor det lykkes Thor at få Midgårdsormen på krogen, holder Thor en mangekantøkse fra tidlig bondestenalder i hånden. I samme bog må jætten Hrungner finde sig $\mathrm{i}$ at blive slået for panden af en tilsvarende gammeldags stridsøkse. De pågældende stenøkser (type

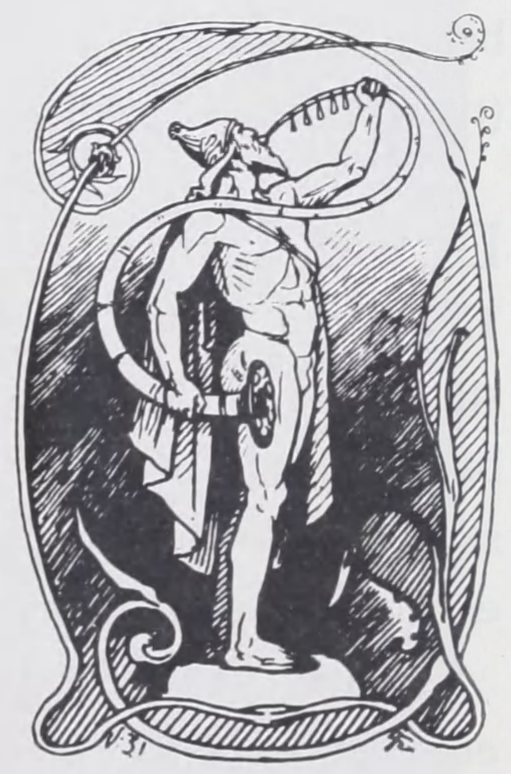

L. Frølich: Heimdal med Gjallerhornet vækker guderne til Kamp ved Ragnarok. Den ældre Eddas gudesange, 1895.

Til Karl Gjellerups ud- 


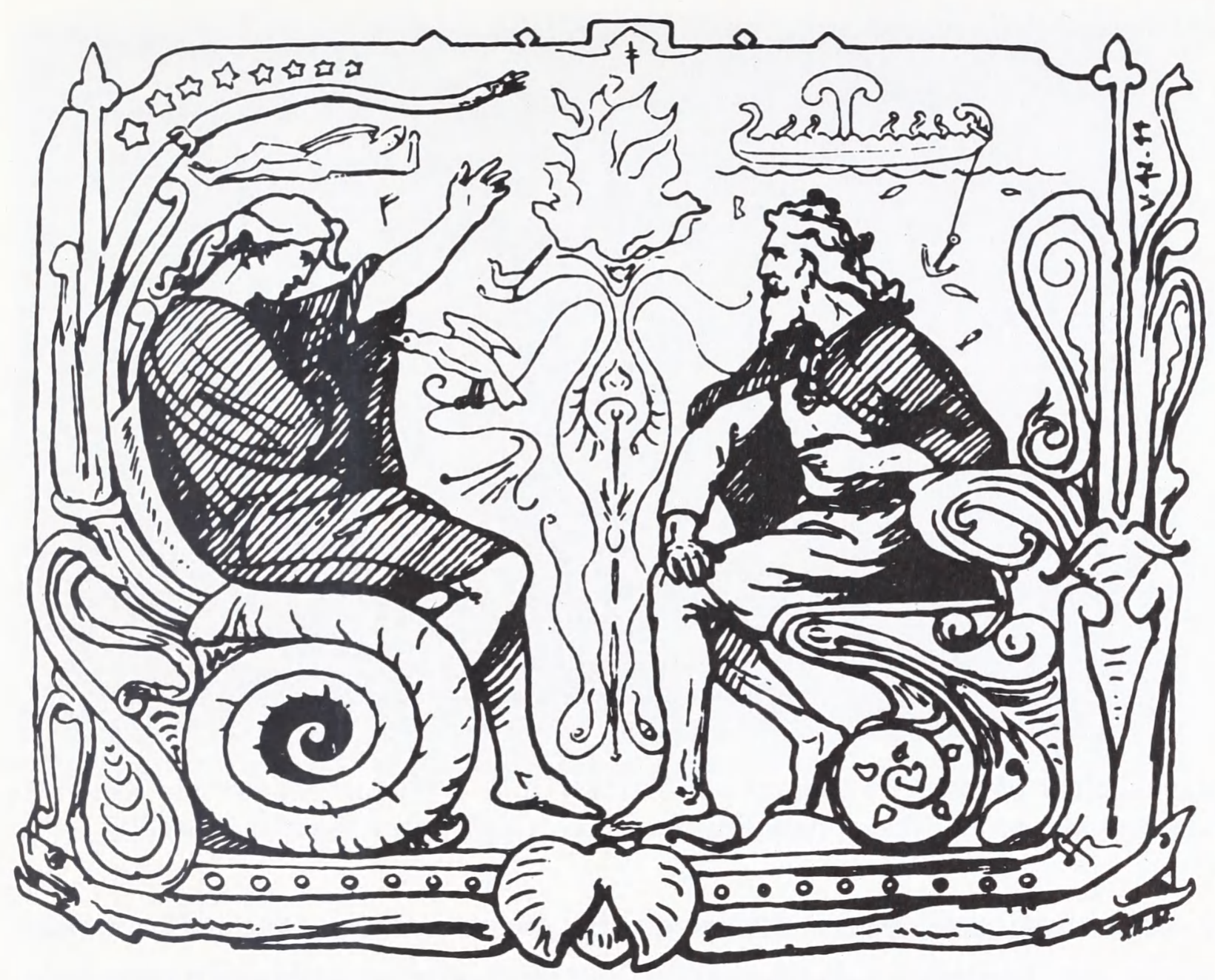

L. Frølich: Dan og Danp i samtale. Den ældre Eddas gudesange, 1895.

indtil 1892 troede, at lurerne blev brugt.

I Den ældre Eddas gudesange kan man også se Odins kone, Frigga, med et ravsmykke fra bondestenalderen om halsen. Odin selv har en halsring fra yngre bronzealder på hovedet til at holde sammen på håret. Ligeledes er frugtbarhedsguden Frej's sværd gengivet som et fra Centraleuropa importeret, såkaldte antennesværd. Det tilhører også yngre bronzealder. I mytologien svinger det sig selv, når det er i klog mands værge, - så det er et godt sværd.

De sociale skel i vikingetidens samfund forklares gennem et digt, Rigs-thula. Rig, som er den forklædte Heimdal, kommer både til en trællehytte, til den frie bondes gård og til overklassens haller. I digtets kun fragmentarisk bevarede slutning, nævnes også kongerne Dan og Danps kostelige haller. De er noget særligt. I Frølichs streg derved, at der på væggen hænger et billede af et bronzealderskib. Forlægget er let at identificere.Det findes på en ragekniv, som sammen med en pincet er fundet ved Avning i Østjylland. De to bronzesager må stamme fra en mandsgrav og udgør et barbersæt fra yngre bronzealder (per. IV) eller ca. år 800 f.v.t. Som et lille, muntert indslag har Frølich udstyret skibet med en moderne anker, så det ikke sejler ud af billedet. 


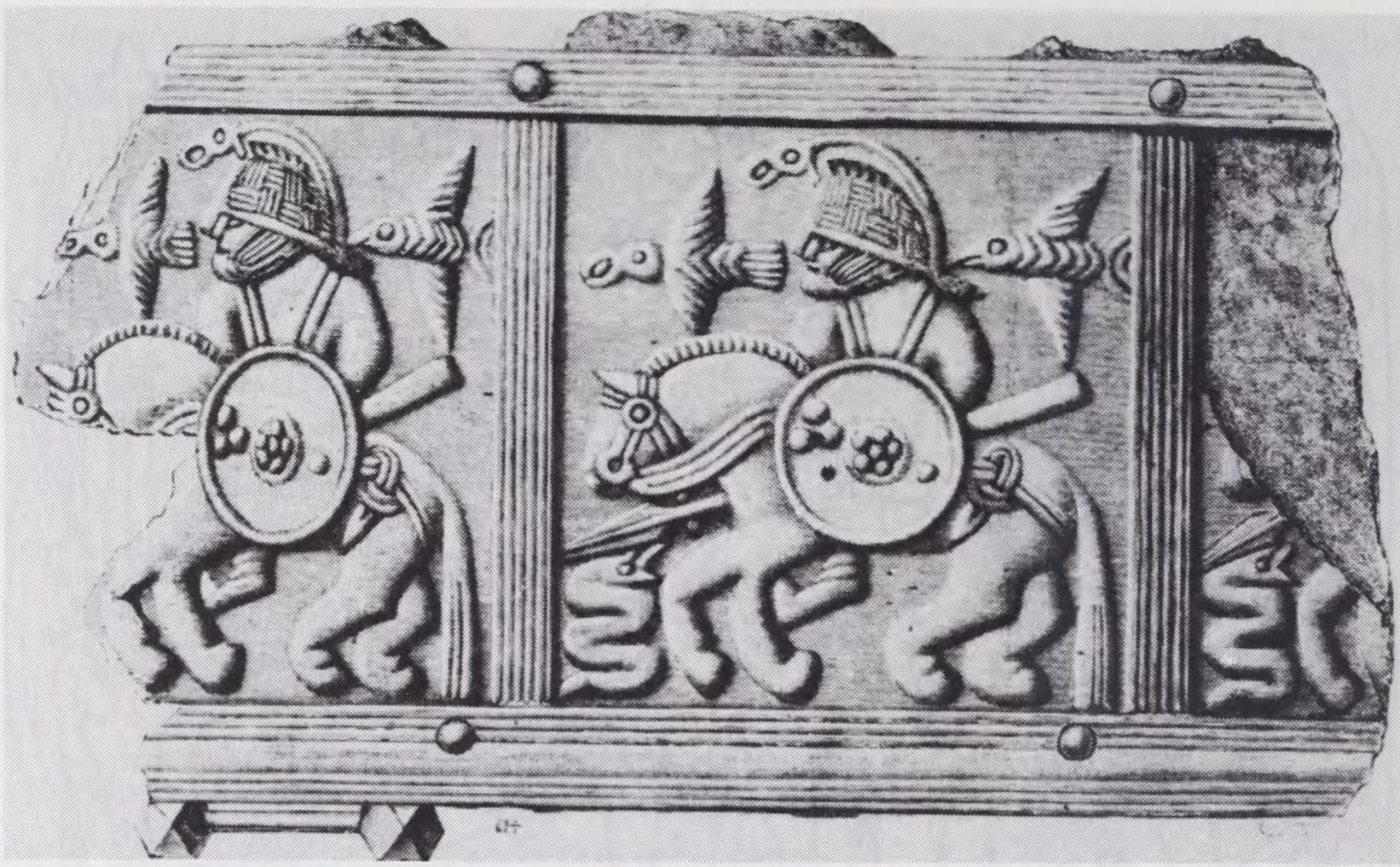

Smykkeplade på hjelm fra bådgrav ved Vendel i Upland. Billedet er dateret til 500-tallet og viser Odin på en firbenet hest. Efter H. Stolpe: Graffältet vid Vendel, Sthlm. 1912.

Båden må have optaget Frølich en del. På en tegneserie fra 1879 ser man således den berømte, islandske skjald, Egil Skallegrimson, ligge i en seng, som er udsmykket med et tilsvarende skib, omend uden anker.

\section{Odin, ca. 550 og 1900 e.v.t.}

I 1881 opdagedes en meget rig bådgrav ved Vendel i Mellemsverige. På stedet udgravedes senere en hel flåde af bådgrave fra jernalderen. I den første grav (Vendel I) var begravet en småkonge i fuld krigsmundering. Han havde hjelm på hovedet og på hjelmen sad en række små billeder i bronzeblik. Et af billederne viser en rytter på en firbenet hest. Han har et spyd i hånden og ved hans skuldre flyver to fugle. Billedet er identificeret som Odin. Han rider på Sleipner og holder spydet Gungner i hånden. Fuglene er ravnene Hugin og Munin. De fortæller gudernes konge om alt, hvad der sker i verden

Billedet er dateret til 500-tallet og er en af de ældste, kendte fremstillinger af guden Odin. Sleipner har således endnu ikke fået 8 ben, som den senere har i den islandske sagaskriver Snorres beskrivelse af Odins hest.

De store, arkæologiske fund ved Vendel vakte betydelig opsigt i slutningen af 1800-tallet. Lorenz Frölich fik naturligt nok også kendskab til dem. I sin senere produktion opgiver han den tidlige, meget stive gengivelse af de nordiske guder, som vi kender fra festen "Den nordiske Højtid", 1845.7 I stedet for sten 


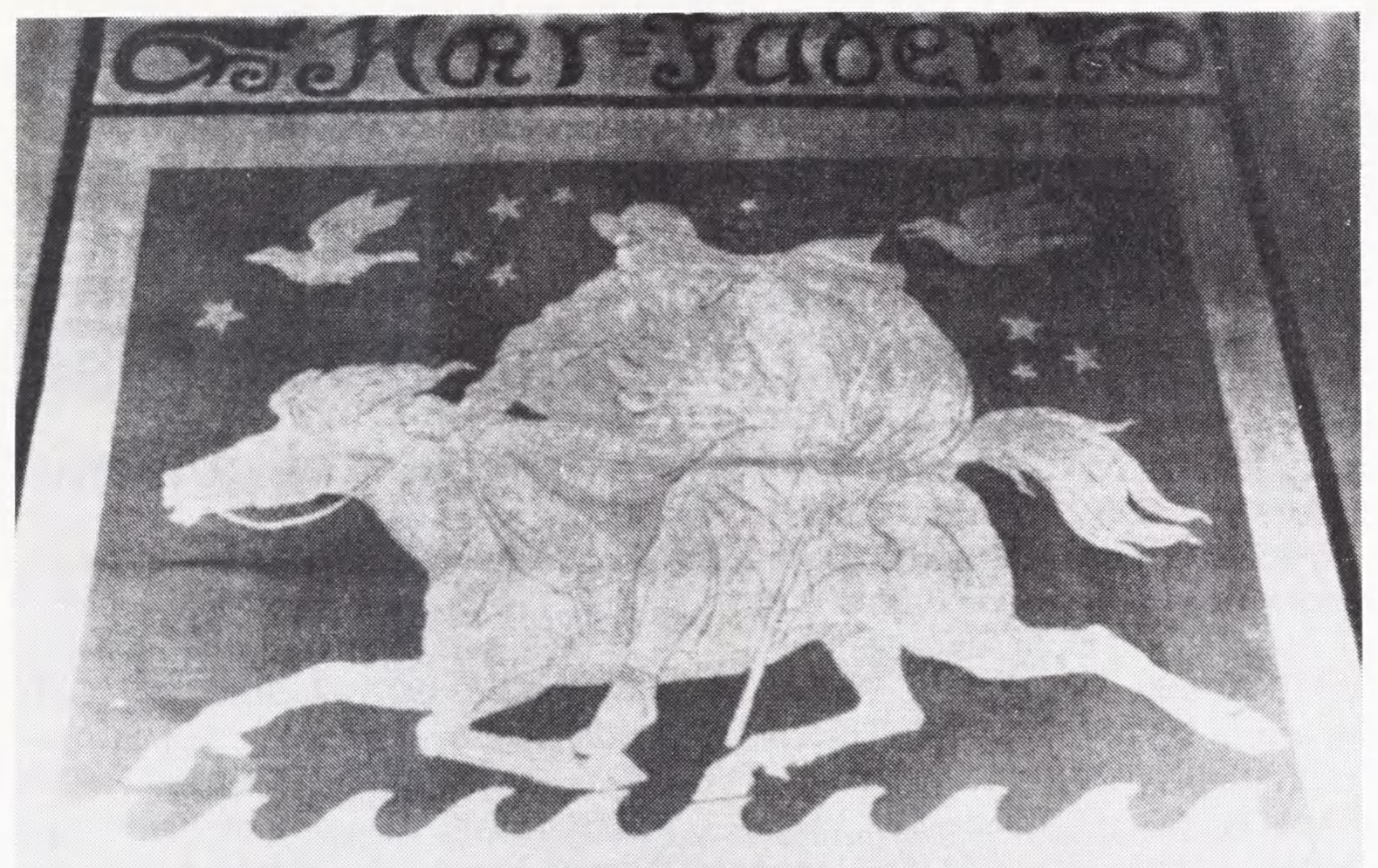

L. Frølich: Odin. Skitse til gobelin på Københavns Rådhus.

kopierer L. Frølich på en af Rådhus-gobelinerne det nyfundne billede af Odin. Motiv og komposition er identiske. Frølich fjerner rytterens skjold, den karakteristiske dyrehovedhjelm samt en enkelt slange.Til gengæld er Hærfader vist i vildt ridt. Her er i næsten bogstavelig forstand tale om et levende billede.

\section{Konklusion}

Dermed er vi nået frem til det centrale resultat af denne lille undersøgelse af Lorenz Frølichs behandling af den nordiske oldtid og de arkæologiske fund.

Gendigtningen af det ca. 1500 år gamle Odin-billede er holdt i et meget enkelt sprog. Billedet er, som Frølichs andre tegninger af de nordiske gude- og heltesagn, genialt blottet for statister. I enkle streger får vi netop sagnet eller historien genfortalt i et levede og meget kraftfuldt formsprog. Det er netop denne evne hos Lorenz Frølich til at tegne sagnets indhold, - hverken mere eller mindre, - der gør, at hans illustrationer på én gang er tidløse og altid aktuelle.

\section{Noter}

1 Lorenz Frølich, Optegnelser om de ældre Konstnere, som have bidraget til min Udvikling. Julebogen 1907, s. 7 ff. samme, Ungdom og Udvikling, Gads Danske Magasin 1906, s. 50 ff. og s. 114

ff. - Lorenz Frølich, Egne Optegnelser og Breve til og fra hans Slægt og Venner. udg. af F. Hendriksen 1920-21. - jf. P. Johansen, Lorenz Frölich, Kunstbladet 1878, s. 129 ff. og s. 155 ff. - P. Krohn, Lorenz 
Frølich. Fortegnelse over Kunstnerens illustrationer, raderinger m.v. Bogvennen $1898-99$, s. 5 ff. - T. Bierfreund, Lorenz Frølich, Ord och Bild 1903, s. 95 ff. - Karl Madsen, Lorenz Frølich, Tilskueren 1908, s. 1008 ff. - Lorens Frølich Udstillingen, Kbh. 1909. - F. Beckett, Lorenz Frølich. Billeder til Danmarkshistorien. Gads danske Magasin 1908-09, s. 133 ff. - S. Müller, Med Frölich s Tegninger til den græske Anthologi. Kunstmuseets Aarsskrift I, 1914, s. 79 ff. T. Oppermann, Lorenz Frølich i Flensburg. Sønderjysk Julealbum 1919, s. 11 ff. - F. Hendriksen, Oplysninger om tidlige illustrationer af Lorenz Frølich. Bogvennen 1921. - H. Glarbo, Lorentz Frølichs Billeder i Flensborg. Tilskueren 1930, s. 210 ff. - H.P. Rhode, Dansk Bogillustration. Kbh. 1949, s. 51 ff. - Hanne Westergaard, Lorenz Frølich. Bogvennen 1964, s. 59 ff. - samme, Lorenz Frølich. Tegninger og illustrationer. Kbh. 1968. - samme, Lorenz Frølich 1820-1908. Kbh. 1974. - J. Sthyr, Dansk grafik 1800-1910. Kbh. 1974. - samme i Dansk biografisk Leksikon.

2 Axel Olrik, Danske Heltesagn, Kbh. 1918. s. $90 \mathrm{ff}$.

3 Nationalmuseets afdeling for Oldtid og Middelalder,nr. MMCXXIV.

4 Harald Ditzel, Uffe hin Spage i Viborg, Viborg 1977.

5 Anonym, Københavns Rådhus. Kbh. 1979.

6 K. Gjellerup, Den ældre Eddas Gudesange, Kbh. 1896, s. 55 og 47.

7 P. Johansen, Nordisk oldtid og dansk kunst, Kbh. 1907. - J. Brøndsted, Oldtidsminderne i Kunsten, Nationalmuseets Arbejdsmark 1958, s. 5 ff. - Hanne Westergaard, Den norrøne tradition i dansk kunst. Islandske håndskrifter og dansk kultur. Det kongelige Bibliotek 1965, s. 49 ff. - Anonym, I Frejas sal. Vejle 1993. 